\title{
PERSEPSI PENDIDIK MADRASAH IBTIDAIYAH SUMATERA BARAT TENTANG KOMPETENSI YANG DIMILIKINYA
}

\author{
Aziza Meria \\ IAIN Padang \\ Email: azizameria2015@yahoo.com
}

Naskah diterima : 30 Agustus 2017, direvisi : 28 September 2017, disetujui : 06 Oktober 2017

\begin{abstract}
This study aims to explore and get a picture of the perception of educators Maadrasah Ibtidaiyah about the competence it has. Along with the birth of Law Number 20 Year 2003 on National Education System and Law Number 14 Year 2005 on Teachers and Lecturers, the teachers have been recognized as professions. As a profession, teachers must have clear and measurable competencies. Teacher competence is four, namely: pedagogic competence, professional competence, social competence, and personal competence. Efforts to improve competence can be done if the educator has a good perception of the competence he has. Please note how the perception of MI educator to pedagogic, personality, social, professional and religious competence, so that later can be known what actions or programs that can be done in improving their competence.
\end{abstract}

Keywords: educator, Madrasah Ibtidaiyah, competence

Pengutipan: Meria, Aziza. (2017). Persepsi Pendidik Madrasah Ibtidaiyah Sumatera Barat Tentang Kompetisi yang Dimilikinya. JMIE: Journal of Madrasah Ibtidaiyah Education, 1(2), 2017, 227-245. jmie.v1i2.43. 


\section{Pendahuluan}

Eksistensi guru dalam bidang pendidikan dan pembelajaran sampai saat sekarang ini masih berperan penting dalam mencapai tujuan pendidikan dan pembelajaran. Keberhasilan program pendidikan tergantung kepada delapan standar yakni: pendidik, peserta didik, proses pembelajaran, sarana dan prasarana, lingkungan pendidikan, biaya, kurikulum, dan evaluasi (Sofyan, 2013:134). Pendidik atau guru (UU RI No. 14 tahun 2005, 2006:2) merupakan faktor yang paling utama terhadap berhasil tidaknya program pendidikan. Pendidikan yang bermutu sangat tergantung kepada mutu pendidikan itu sendiri. Guru yang bermutu atau profesional adalah guru yang dalam melaksanakan tugas keguruannya mendasarkan langkah pada ketentuan yang berlaku dan mengabaikan segala macam pengkondisian yang bersifat egois dan rekayasa (Saroni, 2011:7). Pengakuan resmi bawah seorang guru profesional menurut UU RI No. 14 Tahun 2005 (2006:3) tentang Guru dan Dosen adalah dengan dimilikinya sertifikat pendidik oleh guru.

Tuntutan guru harus menjadi seorang yang profesional sesuai dengan ajaran Islam, di mana seseorang apabila mengerjakan sesuatu harus berkerja dengan sepenuh hati. Sebagaimana dalam surah al-An'am ayat 135 yang artinya: "Katakanlah: "hai kaumku, berbuatlah sepenuh kemampuanmu, sesungguhnya aku pun berbuat (pula). Kelak kamu akan mengetahui, siapakah (di antara kita) yang akan memperoleh hasil yang baik di dunia ini. Sesungguhnya, orang-orang yang zalim tidak akan mendapat keberuntungan".

Ayat di atas menyatakan bahwa dalam melakukan perkerjaan, seseorang harus melakukannya dengan sepenuh hati. Sepenuh hati adalah melakukan dengan keikhlasan, berniat baik, dengan segala ilmu yang dimiliki, bersungguh-sungguh dan agar bermanfaat bagi orang lain. Begitu juga seorang guru atau pendidik, diharapkan mendidik peserta didik dengan sepenuh hati, agar peserta didik mampu mengembangkan segala potensinya dan mencapai tujuan pendidikannya.

Guru di dalam Islam bukan hanya sekedar mendidik dan mengajar akan tetapi sebagai orang yang melakukan pensucian jiwa peserta didik yakni agar dapat mendekatkan diri kepada Allah, menjauhkannya dari keburukan agar tetap berada dalam fitrahnya. Selanjutnya baru menyampaikan pengetahuan untuk direalisasikannya dalam kehidupan (Ramayulis, 2013:11).

Seiring dengan lahirnya Undang-Undang Nomor 20 Tahun 2003 tentang Sistem Pendidikan Nasional dan Undang-Undang Nomor 14 Tahun 2005 tentang Guru dan Dosen maka guru sudah diakui sebagai jabatan profesi. Sebagai jabatan profesi tentu guru harus memiliki kompetensi yang jelas dan terukur. Kompetensi guru ada empat, yakni: kompetensi pedagogik, kompetensi profesional, kompetensi sosial, dan kompetensi personal (Musfah, 2011:30). Kualifikasi pendidikannya minimal S.1/D.IV. Guru yang sudah memiliki semua persyaratan tersebut dapat dinyatakan sebagai guru profesional yang ditandai dengan pemberian sertifikat pendidik. Dengan adanya pengakuan sebagai guru profesional, yang bersangkutan pun berhak menerima tunjangan profesi.

Data tahun 2015 bahwa di Sumatera Barat terdapat 2.267 guru kelas di Madrasah Ibtidaiyah dan yang disertifikasi hanya 889 guru. Berarti masih ada 1.378 guru yang berpeluang mengikuti PPG. melihat data yang ada berarti masih banyak pendidik yang harus meningkatkan kompetensinya, baik itu kompetensi sebagai tuntutan profesional ataupun kompetensi yang memang seharusnya dimiliki sebagai seorang pendidik. 
Pendidik MI atau pendidik di lembaga lainnya, sebagian besar masih berpikir bahwa kompetensi perlu dimiliki dan ditingkatkan hanya untuk mendapatkan sertifikasi guru, oleh sebab itu kebanyakkan guru yang sudah mendapatkan sertifikasi merasa tidak perlu lagi untuk meningkatkatkan kompetensinya.

Berdasarkan teori dan fakta di lapangan, maka perlu diteliti "Bagaimana persepsi pendidik MI tentang kompetensi yang dimilikinya”. Penelitian ini bertujuan untuk memberikan gambaran dan data awal tentang bagaimana persepsi pendidik MI Sumatera Barat tentang kompetensi yang dimiliki sehingga mereka tahu kemampuan mereka dan pandangan mereka tentang kemampuan mereka itu. Oleh sebab itu pertanyaan penelitian ini adalah: 1) Bagaimana persepsi guru MI Sumatera Barat tentang kompetensi pedagogik yang dimiliki saat ini? 2) Bagaimana persepsi guru MI Sumatera Barat tentang kompetensi kepribadian yang dimiliki saat ini? 3) Bagaimana persepsi guru MI Sumatera Barat tentang kompetensi sosial yang dimiliki saat ini? 4) Bagaimana persepsi guru MI Sumatera Barat tentang kompetensi profesional yang dimiliki saat ini? 5) Bagaimana persepsi guru MI Sumatera Barat tentang kompetensi keagamaan yang dimiliki saat ini?

\section{Pembahasan Teoritik}

Kompetensi adalah kumpulan pengetahuan, prilaku dan keterampilan yang harus dimiliki guru untuk mencapai tujuan pembelajaran dan pendidikan. Kompetensi diperoleh melalui pendidikan, pelatihan, belajar mandiri dengan memanfaatkan sumber belajar (Musfah, 2011:27). Len Holmes mendefenisikan: A competence is a description of something wich a person who work a givem accupational area should be able to do. It is description of any action, behavior or outcame wich a person should be able to demonstrate (Suyanto, 2013:39). Sedangkan keterangan tentang kompetensi dalam UU RI Nomor 14 Tahun 2005 tentang Guru dan Dosen (2006:8) dinyatakan pada pasal 10 kompetensi guru sebagaimana yang dimaksud dalam pasal 8 meliputi kompotensi pedagogik, kepribadian, profesionalitas dan sosial. Istilah kompetensi dalam realitanya tidak dapat dipisahkan dari istilah sertifikasi dan profesi guru. Profesi adalah bidang perkerjaan yang dilandasi pendidikan keahlian (keterampilan, kejuruan dan sebagainya) tertentu (Nurdin, 2005:13). Berdasarkan pengertian di atas, maka profesi guru adalah bidang perkerjaan mendidik yang dilandasi pendidikan keahlian (berlatar belakang pendidikan/kependidikan) tertentu. Pengertian di atas diperkuat dalam Websters New Worl Dictionary, sebagaimana yang terdapat dalam buku Profesi dan Etika Keguruan karangan Ramayulis bahwa profesi adalah suatu perkerjaan yang menuntut pendidikan tinggi dalam liberal art atau science, dan biasanya meliputi perkerjaan mental dan bukan perkerjaan manual, seperti mengajar, keinsinyuran, mengarang, dan sebagainya (Ramayulis, 2013:27). Sedangkan sertifikasi adalah proses pemberian sertifikat pendidik untuk guru dan dosen. Dengan kata lain sertifikasi adalah proses pemberian pengakuan bahwa seseorang telah memiliki kompetensi untuk melaksanakan pelayanan pendidikan pada satuan pendidikan tertentu (Istarani \& Pulungan, 2015:217).

Houle mengemukakan ciri-ciri suatu perkerjaan yang profesional adalah: Pertama. Harus memiliki landasan pengetahuan yang kuat. Kedua. Berdasarkan atas kompetensi individual, bukan atas dasar KKN (Korupsi, Kolusi, dan Nepotisme). Ketiga. Memiliki sistem seleksi dan sertifikasi. Keempat. Ada kerjasama dan kompetisi yang sehat antar sejawat. Kelima. Adanya kesadaran profesional yang tinggi. Keenam. Memiliki prinsip-prinsip etik. Ketujuh. Meiliki sistem sanksi profesi. Kedelapan. Adanya militansi individual. 
Kesembilan. Memiliki organisasi profesi (Muhaimin, 2003:64). Pendapat Hule di atas, apabila dikaitkan dengan guru profesi, maka seorang guru harus memiliki kompetensi individual dan kesadaran profesional yang tinggi, dan itu ditunjukkan dengan memiliki kepribadian yang baik, kemampuan untuk mengajar berdasarkan ilmu kependidikan, dan pengakuan sebagai pendidik dengan adanya sertifikat sebagai seorang pendidik. Prinsip etik dan memiliki organisasi profesi, menunjukkan bahwa guru harus memiliki kompetensi sosial yang baik dengan orang-orang disekelilingnya.

Oleh sebab itu sebagai guru, khususnya guru di jenjang pendidikan dasar harus dapat menjadi guru yang efektif dengan bercirikan: Pertama. Memiliki pengetahuan terkait dengan iklim belajar di kelas. Kedua. Kemampuan terkait dengan manajemen strategi pembelajaran. Ketiga. Kemampuan dalam pemberian umpan balik dan penguatan dalam pembelajaran. Keempat. Memiliki kemampuan terkait dengan peningkatan kemampuan diri (Tilaar dalam Nafis, 2013:127).

Sayyed Hossein Nashr dalam bukunya "Islam and the Challenge of the 21 Century" mengemukakan sejumlah tantangan yang dihadapi dunia Islam pada abad 21 yaitu: Kesatu. Krisis lingkungan. Kedua. Tatanan global. Ketiga. Posmodernis. Keempat. Sekularisasi kehidupan. Kelima. Krisis ilmu pengetahuan dan teknologi. Keenam. Penetrasi nilai-nilai non Islam. Ketujuh. Citra Islam. Kedelapan. Sikap terhadap peradaban lain. Kesembilan. Feminimisme. Kesepuluh. Hak asasi manusia. Kesebelas. Tantangan internal (Azra, 1999:32). Sedangkan obat untuk mengatasi berbagai problem masyarakat dan penyakit sosial lainnya adalah to return to god through religion.

Pada agama Islam, seorang guru harus memiliki peran bukan sebagai orang yang menyampaikan ilmu di kelas, tetapi guru berperan dalam pembentukkan intelektual, moral sosial, dan pelatih keterampilan peserta didik. Guru harus berperan sebagai murabbiy, mu'allim, mursyid, mudarris, dan mu'adib. Sebagai murabby, guru mampu membentuk kepribadian agar siswa tidak menjadi orang yang membawa petaka bagi lingkungannya. Sebagai mursyid, guru dapat menjadi tauladan dan konsultan. Sebagai mudarris, guru memiliki kepekaan intelektual dan mampu memperbaharui pengetahuan peserta didik, dapat melatih keterampilan siswa sesuai dengan bakat dan minatnya. Sebagai mu'addib, guru mampu membangun peradaban yang berkualitas di masa depan (Langgulung, 1988; Muhaimin, 2003:206).

Perkerjaan sebagai guru adalah perkerjaan yang menuntut tanggung jawab moral, kompetensi khusus dan profesionalisme. Terlihat dari Bab 1 Undang-undang Guru dan Dosen pasal 1 ayat 1 yang menyatakan bahwa guru adalah pendidikan profesional dengan tugas utama mendidik, mengajar, membimbing, mengarahkan, melatih, menilai, dan mengevaluasi pendidikan pada anak usia dini jalur pendidikan formal, pendidikan dasar, dan pendidian menengah. Tanggungjawab moral seorang guru adalah tanggungjawab kepada masyarakat yang telah mempercayakan anak mereka untuk dididik, melalui interaksi edukasi yang dilakukan mampu menumbuhkan kepribadian dan sosial yang baik. Kompetensi khusus yang harus dimiliki guru adalah kemampuan menyelesaikan masalah yang tidak dapat diselesaikan orang lain, menjadi panutan bagi peserta didik dan masyarakat. Artinya guru harus memiliki moral dan nilai-nilai kehidupan yang baik, di antaranya nilai agama yang terintegrasi dalam kehidupannya. Sedangkan tuntutan profesionalisme adalah guru harus bersikap dan bertindak secara profesional pada saat menyelenggarakan proses pendidikan agar hasilnya maksimal dan efektif (Saroni, 2011:89-97). 
Berdasarkan uraian di atas, maka kompetensi khusus yang dimaksud dalam perkerjaan guru salah satunya adalah memiliki kepribadian, sosial, dan intelektual yang berlandaskan pada ajaran agama yang di anut. Sehingga guru dapat menjadi panutan atau model bagi peserta didik dan masyarakat dalam menjalankan kehidupan sehari-hari.

Aspek spiritual atau keagamaan pada seorang guru merupakan kompetensi pendukung yang wajib dimiliki. Ini dikuatkan oleh pengertian kompetensi menurut E. Mulyasa bahwa kompetensi guru merupakan perpaduan antara kemampuan personal, keilmuan, teknologi, sosial, dan spiritual, yang secara kaffah membentuk kompetensi standar profesi guru, yang mencakup penguasaan materi, pemahaman terhadap peserta didik, pembelajaran yang mendidik, pengembangan pribadi dan profesionalitas (Musfah, :27).

Tujuan pendidikan nasional akan dapat diraih jika para guru betul-betul berkompeten. Kompetensi yang harus dimiliki oleh guru berdasarkan PP No. 19 Tahun 2005 tentang Standar Nasional Pendidikan (30-55; Danim, 2010:22-27; Suyanto \& Asep Jihad, 2013:40) adalah:1) Kompetensi pedagogis. Kompetensi pedagogis adalah kemampuan dalam pengelolaan peserta didik yang meliputi: a) Pemahaman wawasan atau landasan pendidikan. Seorang guru harus memahami hakikat pendidikan dan konsep yang terkait dengannya. Di antaranya yaitu fungsi dan peran lembaga pendidikan, konsep pendidikan seumur hidup dan berbagai implikasinya, peranan keluarga dan masyarakat dalam pendidikan, pengaruh timbal balik antara sekolah, keluarga, dan masyarakat, sistem pendidikan nasional, dan inovasi pendidikan, b) Pemahaman tentang peserta didik. Guru harus mengenal dan memahami siswa dengan baik, memahami tahap perkembangan yang telah dicapainya, kemampuannya, keunggulan dan kekurangannya, hambatan yang dihadapi serta faktor dominan yang dihadapinya, c) Pengembangan kurikulum atau silabus. Setiap guru menggunakan buku sebagai bahan ajar, buku pelajaran banyak tersedia, demikian pula buku penunjang. Guru dapat mengadaptasi materi yang akan diajarkan, dari buku-buku yang telah distandarisasi, d) Perancangan pembelajaran. Guru efektif mengatur kelas dengan prosedur dan mampu menyiapkannya. Perancangan pembelajaran dapat menimbulkan dampak positif berikut ini Pertama, siswa akan dapat selalu mendapatkan pengetahuan baru dari guru, dan tidak akan terjadi pengulangan materi yang tidak perlu. Kedua, menumbuhkan kepercayaan siswa kepada guru sehingga mereka akan senang dan giat belajar, e) Pelaksanaan pembelajaran yang mendidik dan dialogis. Pada anak-anak dan remaja, inisiatif belajar harus muncul dari guru, karena mereka pada umumnya belum memahami pentingnya belajar. Maka, guru harus mampu mempersiapkan pembelajaran yang memancing rasa ingin tau siswa melalui dialogis, f) Evaluasi hasil belajar. Kesuksesan sebagai guru, tergantung pada pemahamannya pada penilaian pembelajaran, dan kemampuannya berkerja efektif dalam penilainnya. Penilaian adalah proses pengumpulan dan pengolahan informasi untuk mengukur dan menilai pencapaian hasil belajar peserta didik, g) Pengembangan peserta didik untuk mengaktualisasikan berbagai potensi yang dimilikinya. Belajar merupakan proses dimana pengetahuan, konsep, keterampilan dan perilaku diperoleh dan dipahami, diterapkan, dan dikembangkan .anak-anak mengetahui perasaan rekannya melalui belajar. Maka, belajar merupakan proses perkembangan kognitif, sosial, dan prilaku. 2) Kompetensi kepribadian (Nurdin, 2004:200). Kompetensi kepribadian yaitu kemampuan kepribadian yang: a) Berakhlak mulia. Tujuan pendidikan nasional agar dapat menjadikan peserta diik berakhlak mulia. Tujuan ini akan tercapai apabila guru memiliki akhlak mulia, b) Mantap, stabil, dan dewasa. Guru harus memiliki standar kualtas pribadi tertentu yang mencakup tanggung jawab, mandiri, disisplin, dan wibawa. Minimal 
ada tiga ciri kedewasaan: Pertama, orang dewasa yang memiliki tujuan hidup, yaitu sekumpulan nilai yang diyakini kebenarannya dan menjadi pegangan hidupnya. Kedua, orang yang mampu melihat segala sesuatu dengan objektif. Ketiga, orang yang bisa bertanggung jawab, c) Arif dan bijaksana, d) Menjadi teladan, e) Mengevaluasi kinerja sendiri. Pengalaman mengajar di kelas memberikan wawasan bagi guru memahami karakter anak-anak dan bagaimana dengan baik menghadapi keragaman tersebut. Guru jadi tahu metode yang terbaik bagi mata pelajaran apa, karena ia pernah mencobanya berkali-kali, f) Mengembangkan diri. Di antara sifat yang harus dimiliki guru adalah pembelajaran yang baik atau pembelajaran mandiri, yaitu semangat yang besar untuk menuntut ilmu, g) Religius. 3) Kompetensi sosial. Kompetensi sosial merupakan kemampuan pendidik sebagai bagian dari masyarakat untuk: a) Berkomunikasi lisan dan tulisan , b) Menggunakan teknologi informasi dan komunikasi secara fungsional, c) Bergaul secara efektif dengan peserta didik, sesama pendidik, tenaga kependidikan, orang tua siswa, d) Bergaul santun dengan masyarakat sekitar. 4) Kompetensi profesional. Kompetensi profesional adalah kemampuan penguasaan materi secara luas dan mendalam yang meliputi: a) Konsep, struktur, dan metode keilmuan atau teknologi atau seni yang menaungi atau kohoren dengan materi ajar, b) Materi ajar yang ada dalam kurikulum sekolah, c) Hubungan konsep antar mata pelajaran terkait, d) Penerapan konsep keilmuan dalam kehidupan sehari-hari, e) Kompetisi secara profesional dalam konteks global dengan tetap melestarikan nilai budaya nasional.

Seorang guru berkewajiban untuk berusaha dan berupaya dalam meningkatkan dan mengembangkan kompetensinya. Secara formal, untuk menjadi profesional guru menurut Rizali, Darma, dan Sidi (2009:78) diisyaratkan memenuhi kualifikasi akademik minimum dan bersertifikat pendidik. Di dalam UU Nomor 74 tahun 2008 dibedakan antara pembinaan dan pengembangan kompetensi guru yang belum dan yang sudah berkualifikasi S-1 atau D-IV. Pengembangan dan peningkatan kualifikasi akademik dan kompetensi bagi guru yang belum memenuhi kualifikasi S-1 atau D-IV melalui pendidikan tinggi S-1 atau program D-IV, pada perguruan tinggi yang menyelenggarakan program pendidikan tenaga kependidikan atau program non kependidikan yang terakreditasi. Sedangkan pengembangan dan peningkatan kompetensi bagi guru yang sudah memiliki sertifikat pendidik dilakukan melalui sistem pembinaan dan pengembangan keprofesian guru berkelanjutan yang dikaitkan dengan perolehan angka kredit jabatan fungsional (Danim, 2010:18-19).

Kegiatan dalam rangka meningkatkan kompetensi guru adalah perlu dilakukannya uji kompetensi guru. Uji kompetensi secara teoritis dan praktis sangat penting di antaranya: Kesatu. Sebagai alat untuk mengembangkan standar kompetensi profesional guru. Kedua. Merupakan alat untuk seleksi penerimaan guru. Ketiga. Untuk pengelompokkan guru. Keempat. Sebagai bahan acuan dalam pengembangan kurikulum. Kelima. Merupakan alat pembinaan guru. Keenam. Mendorong kegiatan dan hasil belajar (Mulyasa, 205:188-190).

Keberlangsungan perkembangan kompetensi guru ditentukan oleh faktor internal dan eksternal. Internal adalah dukungan pihak luar sedangkan internal adalah dorongan dari dalam diri guru. Faktor eksternal yang sangat medorong peningkatan kompetensi guru adalah melalui kegiatan KKG/MGMP. Tantangan yang dapat memacu guru dalam KKG/MGMP untuk berkembang adalah diantaranya tantangan untuk meningkatkan kualifikasi setingkat S1 dan D IV dan sertifikasi profesi sebagai syarat untuk mendapatkan tunjangan profesi (Zainal, dkk, 2016:148). 


\section{Metode Penelitian}

Penelitian ini merupakan penelitian lapangan (field research) (Mardalis, 1993:28). Penelitian ini dalam pengumpulan dan analisis menggunakan metode mixing method (Sugiyono, 2009:26). Data yang akan dikumpulkan dan dianalisis, penelitian ini menggunakan pendekatan kuantitatif dan kualitatif.. Data yang ingin didapatkan dari dua pendekatan ini ada berkenaan dengan persepsi kemampuan atau kompetensi pendidik MI di Sumatera Barat. Berdasarkan batasan masalah penelitian ini, maka data berkenaan dengan persepsi pendidik MI Sumatera Barat berkenaan dengan kemampuan atau kompetensinya, menggunakan data kuantitatif dan data kualitatif.

Sumber data penelitian ini adalah pihak-pihak yang memberikan informasi atau pelaku fakta sehingga didapatkan informasi atau data. Populasi penelitian ini adalah, pendidik MI Sumatera Barat. Kemudian populasi terjangkaunya adalah, seluruh pendidik MI yang menjadi guru kelas. Pengisian angket berupa persepsi kompetensi guru MI. Berdasarkan jumlah guru MI yang belum sertifikasi 1998, yang menjadi populasi, sampel di ambil secara random sampling. Maka penulis menetapkan sampel yang akan ditarik adalah sebesar $30 \%$ dari populasi (Surakhmad, 1970:91). Maka peneliti mengambil populasi terjangkaumya atau populasi target (Neuman, 2016:275) adalah guru MI di beberapa daerah di Sumatera Barat. Dari 19 Kabupaten Kota yang ada di Sumatera Barat, sampel yang diambil MI Negeri dan Swasta yang ada di 6 kabupaten/kota yaitu: Kota Padang, Kota Pariaman, Kabupaten Tanah Datar, Kabupaten Pesisir Selatan, Kabupaten 50 Kota, dan Kota Payakumbuh. Daerah ini ditentukan secara random sampling saja, begitu juga dipemilihan MIN/MIS yang mewakili masing-masing daerah, juga digunakan random sampling (Setyosari, 2010:170).

\section{Tabel 1}

\section{Daftar Pendidik MI sebagai Responden Penelitian}

\begin{tabular}{ccc}
\hline No & Kabupaten/Kota & Jumlah Pendidik \\
\hline 1 & Kota Padang & 36 \\
2 & Padang Pariaman & 23 \\
3 & Tanah Datar & 46 \\
4 & 50 Kota & 24 \\
5 & Payakumbuh & 10 \\
6 & Pesisir Selatan & 36 \\
\hline
\end{tabular}

Sedangkan untuk pengambilan data kualitatif, digunakan teknik purposeful sampling (Neuman, 2016:298), di mana peneliti juga mewawancarai beberapa pihak yang dapat memberikan data berkenaan dengan bagaimana pandangan pendidik terhadap kompetensinya dan solusinya.

Analisa data yang dilakukan dalam penelitian ini didasarkan pada tujuan penelitian dilakukan. Penelitian ini berusaha untuk mengeksplor persepsi sekaitan dengan kondisi kompetensi pendidik MI analisa yang dilakukan: pertama, analisis Statistika deskriptif (Neuman, 2016:248). Teknik analisis statistik merupakan perhitungan persentasi data nominal. Kedua, teknik analisis induktif digunakan untuk menganalisis hasil wawancara bebas, di mana analisis ini dapat mengidentifikasi pengaruh pembentukan timbal balik 
interaksi peneliti dengan responden atau informan (Ahmadi, 2016:25). Ketiga, analisis taksonomi. Yaitu bentuk analisis kualitatif yang nantinya akan membangun faktor-faktor yang ada, sehingga terbangun sebuah kesimpulan tentang harapan, solusi dan apa yang menjadi kendala pendidik MI dalam meningkatkan kompetensinya.

\section{Temuan Penelitian}

Persepsi Guru Madrasah Ibtidaiyah tentang Kompetensi Pedagogik yang Dimiliki

Tabel 2

\section{Kemampuan Pedagogik Pendidik MI}

\begin{tabular}{|c|c|c|c|c|c|c|c|c|c|c|c|c|c|}
\hline \multirow{2}{*}{$\mathrm{NO}$} & \multirow{2}{*}{\multicolumn{3}{|c|}{ ITEM ANGKET }} & \multicolumn{5}{|c|}{ PILIHAN } & \multicolumn{5}{|c|}{ PERSENTASE ( \% ) } \\
\hline & & & & 5 & 4 & 3 & 2 & 1 & 5 & 4 & 3 & 2 & 1 \\
\hline \multirow[t]{7}{*}{1} & A. & Ko1 & npetensi Pedagogik & 3 & 43 & 52 & 59 & 18 & 1,7 & 24,6 & 29,7 & 33,7 & 10,9 \\
\hline & & & $\begin{array}{l}\text { 1. Memahami } \\
\text { Peserta Didik } \\
\text { dengan me- } \\
\text { manfaatkan } \\
\text { prinsip-prin- } \\
\text { sip perkem- } \\
\text { bangan kog- } \\
\text { nitif }\end{array}$ & & & & & & & & & & \\
\hline & & 2. & $\begin{array}{l}\text { Memahami peserta } \\
\text { didik dengan me- } \\
\text { manfaatkan prin- } \\
\text { sip-prnsip kepriba- } \\
\text { dian }\end{array}$ & 5 & 46 & 39 & 45 & 40 & 2,8 & 26,3 & 22,3 & 25,7 & 22,8 \\
\hline & & 3. & $\begin{array}{l}\text { Mengidentifikasi } \\
\text { bekal ajar awal pe- } \\
\text { serta didik }\end{array}$ & 37 & 39 & 42 & 21 & 36 & 21,1 & 22,3 & 24 & 12 & 20,6 \\
\hline & & 4. & $\begin{array}{l}\text { Memahami lan- } \\
\text { dasan kependidikan }\end{array}$ & 27 & 38 & 39 & 61 & 10 & 15,4 & 21,7 & 22,3 & 34,8 & 5,7 \\
\hline & & 5. & $\begin{array}{l}\text { Menerapkan teori } \\
\text { belajar dan pembe- } \\
\text { lajaran }\end{array}$ & 59 & 34 & 52 & 18 & 12 & 33,7 & 19,4 & 29,7 & 10,9 & 6,8 \\
\hline & & 6. & $\begin{array}{l}\text { Menentukan strate- } \\
\text { gi pembelajaran } \\
\text { berdasarkan karak- } \\
\text { teristik peserta didik }\end{array}$ & 10 & 32 & 66 & 34 & 33 & 5,7 & 18,2 & 37,7 & 19,4 & 18,8 \\
\hline
\end{tabular}


7. Menentukan strate-

$48 \quad 38$

$52 \quad 45$

$8 \quad 27,4$

$21,7 \quad 29,7 \quad 25,7 \quad 4,5$

gi pembelajaran

berdasarkankom-

petensi yang ingin

dicapai

8. Menentukan strate- $\begin{array}{lllllllllll}30 & 40 & 42 & 37 & 26 & 17,1 & 22,8 & 24 & 21,1 & 14,8\end{array}$

gi pembelajaran

berdasarkan materi

ajar

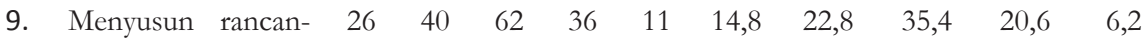

gan pembelajaran

berdasarkan strategi

dipilh

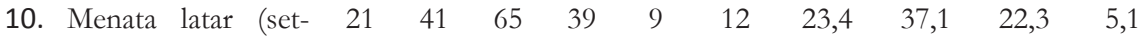
ting) pembelajaran

11. Melaksanakan pem- $\begin{array}{llllllllll}44 & 35 & 42 & 31 & 23 & 25,1 & 20 & 24 & 17,7 & 13,1\end{array}$

belajaran yang kon-

dusif

12. Merancang evaluasi (assessment) pros-

es belajar secara berkesinambungan dengan berbagai metode

13. Merancang eval- $14 \quad 36 \quad 48 \quad 39 \quad \begin{array}{llllllll}38 & 8 & 8 & 20,4 & 27,4 & 22,3 & 21,7\end{array}$ uasi (assessment) hasil belajar secara berkesinambungan dengan berbagai metode

14. Melaksanakan eval- $\begin{array}{llllllllll}24 & 35 & 58 & 31 & 27 & 13,7 & 20 & 33,1 & 17,7 & 15,4\end{array}$ uasi (assessment) proses belajar secara berkesinambungan dengan berbagai metode

15. Melaksanakan eval- $\begin{array}{llllllllll}28 & 35 & 55 & 34 & 23 & 16 & 20 & 31,4 & 19,4 & 13,1\end{array}$ uasi (assessment) hasil belajar secara berkesinambungan dengan berbagai metode 
16. Menganalisis hasil evaluasi proses untuk menentukan tingkat ketuntatasan belajar (mastery learning)

17. Menganalisis hasil evaluasi hasil belajar untuk menentukan tingkat ketuntatasan belajar (mastery learning)

18. Memanfaatkan hasil penilaian pembelajaran untuk perbaikan kualitas program pembelajaran secara umum

19. Memfasilitasi peserta didik untuk pengembangan berbagai potensi akademik

20. Memfasilitasi peserta didik untuk mengembangkan berbagai potensi non akademik

21. Mampu membuat sendiri media pembelajaran

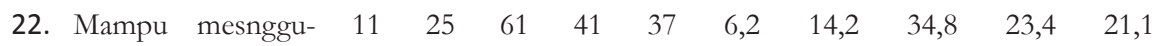
nakan barang elektronik sebagai media pembelajaran

Berdasarkan temuan di lapangan tentang persepsi atau penilaian diri pendidik MI pada kompetensi pedagogik, pada masing-masing item dapat dilihat pendidik menilai diri sendiri, sejauh mana kompetensi yang dimiliki. Pada item memahami peserta didik dengan memanfaatkan prinsip-prinsip perkembangan kognitif dan kepribadian, dari 175 responden sebagian besar guru $(73 \%$ dan $70 \%$ ) cenderung menjawab belum memahami bagaimana memamahami peserta didik dengan berlandaskan pada prinsip-prinsip perkembangan kognitif dalam pembelajaran.

Sedangkan kemampuan untuk mengidentifikasi bekal ajar awal peserta didik, atau kemampuan dalam mempersiapkan pembelajaran, guru cukup mengetahuinya $(56 \%)$. Memahami landasan pendidikn serta menerapkan teori belajar dalam pembelajaran, pendidik 
MI cukup memiliki kemampuan, dibuktikan persentasi masing-masing sebesar $62 \%$ dan $50 \%$. Sedangkan menentukan strategi berdasarkan karakter peserta didik, kompetensi yang ingin dicapai dan materi ajar, kompetensi guru juga cenderung tidak cukup baik, ini dibuktikan dengan masing-masing persentasinya adalah 75\%, 60\%, dan 59\%. Dari persentase ini guru sangat kurang $(75 \%)$ memiliki kemampuan memilih strategi pembelajaran berdasarkan karakterisitik peserta didik.

Kemampuan guru dalam mengelola pembelajaran mulai dari perencanaan sampai pelaksanaan, berdasarkan data yang didapatkan juga cenderung cukup. Dilihat dari penyusunan rancangan pembelajaran, menata setting pembelajaran sampai melaksanakan pembelajaran yang kondusif masing-masing persentasenya adalah 62\%, 64\%, dan 54\%.

Sedangkan kemampuan mengevaluasi pembelajaran guru cenderung kurang memiliki kemampuan dibandingkan perencanaan dan pengelolaan kelas. Persentasi evaluasi pembelajaran dari segi merancang, melaksanakan, dan menganalisis assessment dengan berbagai metode, serta memanfaatkan hasil evaluasi untuk perbaikan masing-masingnya 64\%, 66\% dan 62\%. Pada item mampu memfasilitasi peserta didik pada kegiatan akademik dan non akademik, kompetensi atau kemampuan guru juga cenderung rendah yaitu $64 \%$ dan $73 \%$.

Terakhir di bagian kompetensi pedagogik ini adalah kemampuan pendidik dalam membuat dan menggunakan media. Kemampuan guru dalam membuat media cenderung cukup yaitu 53\%, dan menggunakan media elektronik 79\% dinyatakan kemampuan guru kurang. Sedangkan dari observasi yang dilakukan ketika penyebaran angket, kurangnya kompetensi pedagogik yang dimiliki oleh pendidik MI terlihat dari pengelolaan kelas yang kurang baik, yaitu pada saat pembelajaran berlangsung terlihar peserta didik keluar masuk kelas, rebut di kelas, bahkan ada yang sampai berkelahi. Kondisi seperti itu tidak ditangani oleh pendidik.

Persepsi Guru Madrasah Ibtidaiyah tentang Kompetensi Kepribadian yang Dimiliki

Tabel 3

\section{Kompetensi Kepribadian Pendidik MI}

\begin{tabular}{|c|c|c|c|c|c|c|c|c|c|c|c|c|}
\hline \multirow{2}{*}{$\mathrm{NO}$} & \multirow{2}{*}{\multicolumn{2}{|c|}{ ITEM ANGKET }} & \multicolumn{5}{|c|}{ PILIHAN } & \multicolumn{5}{|c|}{ PERSENTASE ( $\%)$} \\
\hline & & & 5 & 4 & 3 & 2 & 1 & 5 & 4 & 3 & 2 & 1 \\
\hline \multirow[t]{5}{*}{2} & B. & Kompetensi Kepribadian & 52 & 71 & 41 & 19 & 8 & 29,7 & 40,5 & 23,4 & 10,8 & 4,5 \\
\hline & & $\begin{array}{l}\text { 1. Bertindak sesuai } \\
\text { dengan norma } \\
\text { hukum }\end{array}$ & & & & & & & & & & \\
\hline & & $\begin{array}{l}\text { 2. Bertindak sesuai den- } \\
\text { gan norma sosial }\end{array}$ & 66 & 42 & 43 & 24 & 0 & 37,7 & 24 & 24,5 & 13,7 & 0 \\
\hline & & 3. Bangga sebagai guru & 33 & 52 & 41 & 40 & 9 & 18,8 & 29,7 & 23,4 & 22,8 & 5,1 \\
\hline & & $\begin{array}{l}\text { 4. Memiliki konsistensi } \\
\text { dalam bertindak ses- } \\
\text { uai dengan norma }\end{array}$ & 37 & 50 & 31 & 49 & 8 & 21,1 & 28,5 & 17,7 & 28 & 4,5 \\
\hline
\end{tabular}




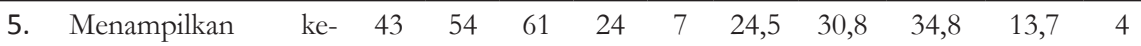
mandirian dalam bertindak sebagai pendidik

6. Memiliki etos kerja se- $\begin{array}{rllllllll}25 & 43 & 65 & 40 & 2 & 14,2 & 24,5 & 37,1 & 22,8\end{array}$ bagai guru

7. Menampilkan tinda- $\begin{array}{llllllllll}22 & 35 & 61 & 32 & 25 & 12,5 & 20 & 34,8 & 18,2\end{array}$ kan yang didasarkan pada kemanfaatan peserta didik

8. Menampilkan tinda- $\begin{array}{llllllllll}32 & 45 & 51 & 34 & 13 & 18,2 & 25,7 & 29,1 & 19,4 & 7,4\end{array}$ kan yang didasarkan pada kemanfaatan sekolah

9. Menampilkan tinda- $\begin{array}{llllllllll}18 & 48 & 52 & 46 & 11 & 10,2 & 27,4 & 29,7 & 26,2 & 6,2\end{array}$ kan yang didasarkan pada kemanfaatan masyarakat

10. Menunjukan keterbukaan dalam berpikir dan bertindak

11. Memiliki perilaku $40 \quad 45 \quad 43 \quad 43 \quad 4 \quad 22,8 \quad 25,7 \quad 24,5 \quad 24,5 \quad 2,2$ yang berpengaruh positif terhadap peserta didik

12. Memiliki perilaku $\begin{array}{lllllllll}32 & 33 & 43 & 36 & 31 & 18,2 & 18,8 & 24,5 & 20,5\end{array}$ yang disegani

13. Bertindak sesuai den- $\begin{array}{llllllllll}33 & 49 & 68 & 21 & 4 & 18,8 & 28 & 38,8 & 12 & 2,2\end{array}$ gan norma agama (iman dan taqwa)

$\begin{array}{lllllllllll}\text { 14. Bertindak jujur } & 32 & 42 & 46 & 51 & 4 & 18,2 & 24 & 26,2 & 29,1 & 2,2\end{array}$

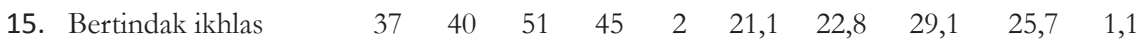

16. Bertindak suka me- $\quad \begin{array}{llllllllll}52 & 56 & 43 & 36 & 8 & 18,2 & 32 & 24,5 & 20,5 & 4,5\end{array}$ nolong

17. Memiliki perilaku $25 \quad 43 \quad 46 \quad 43 \quad 18 \quad 24,5 \quad 24,5 \quad 26,2 \quad 24,5$ yang diteladani peserta didik

Berdasarkan tabel di atas, dapat diketahui data tentang kemampuan pendidik dalam hal kompetensi kepribadian. Kompetensi kepribadian ini menunjukkan bagaimana kepribadian, sikap dan tingkah laku guru. Dilihat dari kepatuhan guru dalam bertindak sesuai norma hukum dan sosial, cenderung baik, yaitu masing-masing $39 \%$ dan $38 \%$. Sedangkan kepribadian sebagai seorang guru akan terlihat dalam sikap kebanggaan sebagai seorang guru, stabil dalam bertindak, mandiri dan memiliki etos kerja juga cenderung baik, ini dapat dilihat dari persentasi kurang yang mengecil yaitu: 51\%, 50\%, 52\% dan 
61\%, dalam hal penampilan prilaku berdasarkan kemanfaatan peserta didik, sekolah dan masyarakat, pendidik MI masih belum cukup baik, persentase masing-masing item adalah $67 \%$, 59\%, dan 62\%. Sedangkan sikap kedewasaan yang dimiliki pendidik MI ditandai dengan kemampuan dan sikap terbuka, berprilaku positif, disegani, dan bertindak sesuai dengan norma agama masih belum cukup baik. Persentase masing-masingnya adalah: 63\%, 51\%, 63\%, dan 53\%. Nilai religius yang tergambar dari kompetensi kepribadian yang dimiliki pendidik MI adalah kejujuran, ikhlas, suka menolong, dan memiliki prilaku yang ditauladani persentasenya adalah 57\%, 56\%, 51\%, dan 61\%.

Mengenai kepribadian pendidik MI, berdasarkan observasi yang dilakukan terlihat masih ada pendidik yang bertingkah laku baik dan sesuai ajaran Islam. Dibuktikan ketika peneliti mengamati di ruang guru, masih banyak pendidik yang memanggil sesame guru "ang" dan "kau“. Padahal itu dilakukan di lingkungan sekolah yang bisa didengar dan ditiru peserta didik. Mereka masih saya mengobrol dan tertawa kelas, ketika pembelajaran berlanjut. Banyak yang terlambat datang ke sekolah disaat peserta didik sudah masuk kelas. Bahkan ketika peserta didik shalat berjamaah, pendidik masih banyak yang ngobrol di ruang guru.

Persepsi Guru Madrasah Ibtidaiyah tentang Kompetensi Sosial yang Dimiliki

Tabel 4

Kompetensi Sosial Pendidik MI

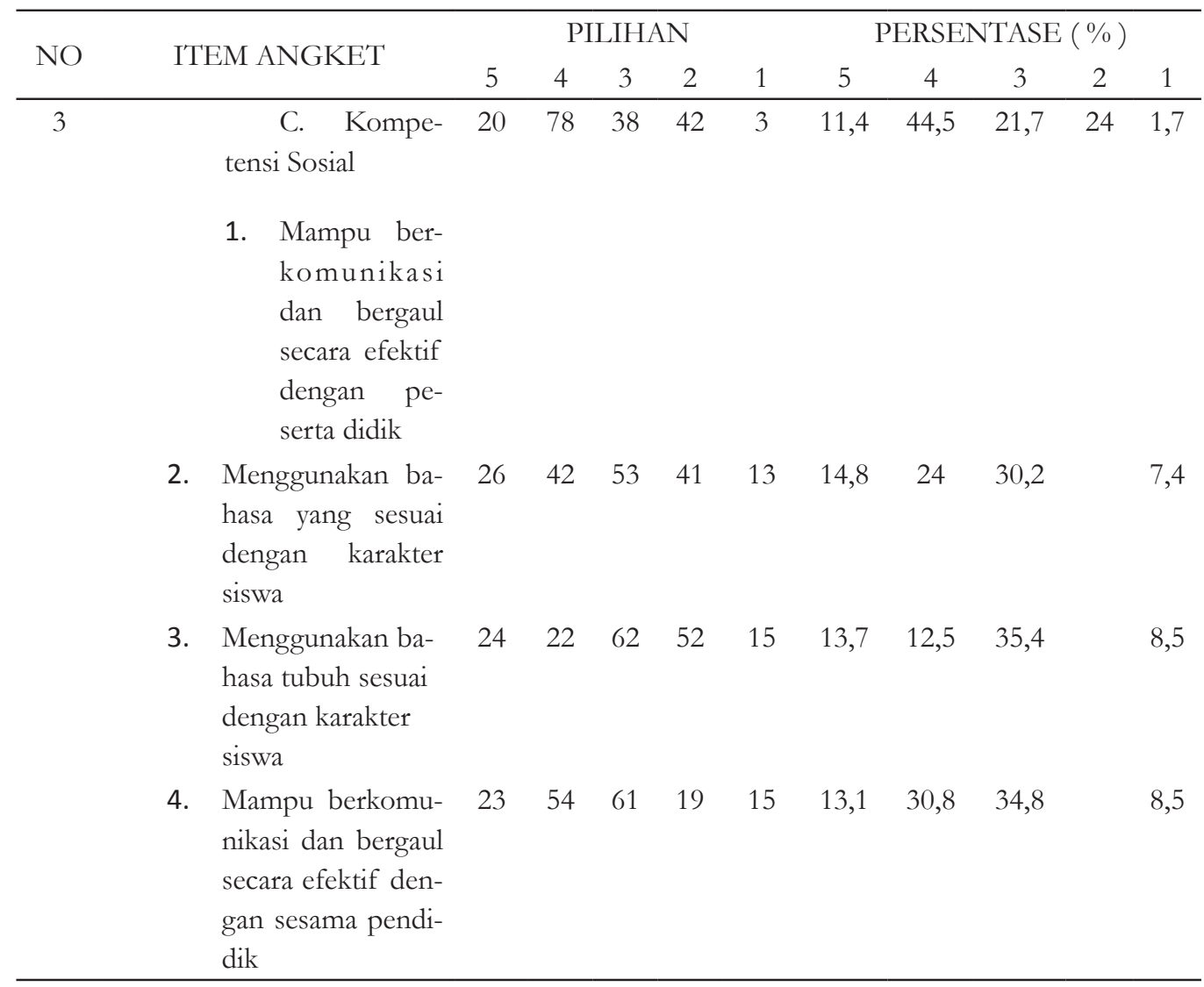



5. Mampu berkomu- $\begin{array}{lllllllll}21 & 45 & 62 & 27 & 20 & 12 & 25,7 & 35,4\end{array}$ nikasi dan bergaul secara efektif den- gan tenaga kepen- didikan
6. Menggunakan bahasa lisan yang sesuai dengan lingkungan kerja
7. Mampu berkomu- $\begin{array}{llllllllll}29 & 47 & 59 & 47 & 7 & 16,5 & 26,8 & 33,7 & 4\end{array}$ nikasi dan bergaul secara efektif den- gan orang tua/wali peserta didik

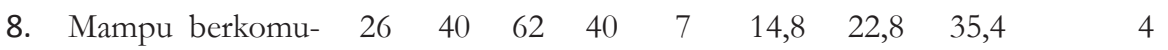 nikasi dan bergaul secara efektif den- gan masyarakat sekitar
$\begin{array}{lllllllllll}\text { 9. } & \text { Berbagul sesuai } & 30 & 48 & 43 & 51 & 17 & 17,1 & 27,4 & 24,5 & 9,7\end{array}$ dengan adat dan kebiasaan setem- pat

Kompetensi sosial pendidik MI, dibagi menjadi 2 kategori yaitu kompetensi yang dilihat dari komunikasi dengan peserta didik, dan orang dewasa seperti rekan sejawat, tenaga kependidikan, orang tua, dan masyarakat sekitar. Komunikasi dengan pendidik berdasarkan dengan efektifitasnya, bahasa lisan dan tubuh yang sesuai dengan karakter siswa, maka persentasi masing-masing adalah 47\%, 61\%, dan73\%. Dari persentase di atas, maka yang paling kurang kemampuan guru adalah dalam menggunakan bahasa tubuh sesuai dengan karakter siswa. Sedangkan komunikasi dengan orang dewasa atau lingkungan sekolah persentasenya adalah 54\%, 63\%,62\%,64\%, dan 62\%. Sedangkan pergaulan sesuai dengan adat setempat adalah $63 \%$ yaitu cenderung kurang. 
Persepsi Guru Madrasah Ibtidaiyah tentang Kompetensi Profesional yang Dimiliki

Tabel 5

Kompetensi Profesional Pendidik MI

\begin{tabular}{ccccccccccccc}
\hline \multirow{2}{*}{ NO } & \multicolumn{4}{c}{ PILIHAN } & \multicolumn{4}{c}{ PERSENTASE ( \% $)$} \\
\hline 4 & 5 & 4 & 3 & 2 & 1 & 5 & 4 & 3 & 2 & 1 \\
\hline & $\begin{array}{c}\text { D. Kompentsi } \\
\text { Profesional }\end{array}$ & 25 & 33 & 8 & 50 & 13 & 14,2 & 18,8 & 4,5 & 28,5 & 7,4
\end{tabular}

1. Memahami materi ajar yang ada dalam kurikulum sekolah

2. Memahami struktur, konsep dan metode keilmuan yang menaungi atau koheren dengan materi ajar

3. Memahami hubungan konsep antar mata pelajaran terkait

$\begin{array}{llllllllllll}\text { 4. Menerapkan kon- } & 30 & 36 & 47 & 40 & 22 & 17,1 & 20,5 & 26,8 & 22,8 & 12,5\end{array}$ sep-konsep keilmuan dalam kehidupan sehari-hari

$\begin{array}{llllllllllll}\text { 5. Menguasai } & \text { lang- } & 10 & 34 & 34 & 42 & 55 & 5,7 & 19,4 & 19,4 & 24 & 31,4\end{array}$ kah-langkah penelitian untuk memperdalam pengetahuan/materi bidang studi

6. Menguasai kajian kritis $\begin{array}{lllllllllll}8 & 35 & 45 & 56 & 31 & 4,5 & 20 & 25,7 & 32 & 17,7\end{array}$ untuk memperdalam pengetahuan/ materi bidang studi

Secara resmi dan perundang-undangan, profesional guru dapat dilihat dari kualifikasi pendidikannya dan sertifikat pendidikannya. Responden hampir seluruhnya memiliki kompetensi keprofesionalan tersebut sesuai dengan yang dinyatakan undang-undang. Akan tetapi keprofesionalan juga dapat dinilai dari beberapa indikator sebagaimana dalam tabel di atas. Akan tetapi berdasarkan kuesioner di atas, ternya di lapangan pendidik MI belum menggambarkan sebagai pendidik profesional. Dilihat dari data yang mengemukakan bahwa pendidik memiliki kemampuan memahami bahan ajar sesuai kurikulum sekolah, memamhami struktur, konsep, dan metode yang konheren dengan materi ajar, serta memahami hubungan konsep antar mata pelajaran terkait cenderung belum cukup baik. Dibuktikan dengan masing-masing persentasenya adalah 63\%,63\% dan 63\%. Menerapkan konsep ilmu dalam kehidupan sehari-hari $62 \%$, sebagai peneliti dan menguasai kajian teoritis untuk memperdalam ilmu persentase masing masing adalah $75 \%$. 
Walaupun keprofesionalan ditetapkan Indang Undang apabila seorang pendidik berijazah S1 dan memiliki sertifikat pendidik, hal itu adalah legalitas formal. Secara fakta, masih banyak pendiik yang terlihat belum professional. Dibuktikan dengan dokumen yang ditemukan di sekolah tentang penelitian atau karya ilmiah guru yang masih sangat sedikit.

Begitu juga dengan kemampuan membuat karya ilmiah, berdasarkan wawancara peneliti dengan pendidik MI dinyatakan bahwa mereka kesulitan naik pangkat karena tidak memiliki karya ilmiah atau penelitian. Hal ini disebabkan mereka tidak memiliki kemampuan dalam membuat karya ilmiah (Mira, 2016).

Persepsi Guru Madrasah Ibtidaiyah tentang Kompetensi Pedagogik yang Dimiliki

Tabel 6

Kompetensi Kegamaan

\begin{tabular}{|c|c|c|c|c|c|c|c|c|c|c|c|}
\hline \multirow{2}{*}{$\mathrm{NO}$} & \multirow{2}{*}{ ITEM ANGKET } & \multicolumn{5}{|c|}{ PILIHAN } & \multicolumn{5}{|c|}{ PERSENTASE ( \% ) } \\
\hline & & 5 & 4 & 3 & 2 & 1 & 5 & 4 & 3 & 2 & 1 \\
\hline \multirow[t]{8}{*}{5} & $\begin{array}{l}\text { E. Kompe- } \\
\text { tensi Agama }\end{array}$ & 26 & 32 & 45 & 53 & 19 & 14,8 & 18,2 & 25,7 & 30,2 & 10,8 \\
\hline & $\begin{array}{l}\text { 1. Mampu memben- } \\
\text { tuk sikap spiritual } \\
\text { peserta didik men- } \\
\text { jadi manusia ber- } \\
\text { taqwa pada Tuhan } \\
\text { Yang Maha Esa }\end{array}$ & & & & & & & & & & \\
\hline & $\begin{array}{l}\text { 2. Memiliki pengeta- } \\
\text { huan akidah yang } \\
\text { baik dan benar }\end{array}$ & 24 & 44 & 43 & 42 & 22 & 20 & 25,1 & 24,5 & 24 & 12,6 \\
\hline & $\begin{array}{l}\text { 3. Memiliki pemaha- } \\
\text { man akidah yang } \\
\text { baik dan benar }\end{array}$ & 23 & 25 & 56 & 46 & 25 & 13,1 & 14,2 & 32 & 26,3 & 14,2 \\
\hline & $\begin{array}{l}\text { 4. Mampu meninte- } \\
\text { grasikan akidah da- } \\
\text { lam kehidupan }\end{array}$ & 22 & 25 & 51 & 42 & 35 & 12,5 & 14,2 & 29,1 & 24 & 20 \\
\hline & $\begin{array}{l}\text { 5. Memiliki pengeta- } \\
\text { huan ibadah yang } \\
\text { baik dan benar }\end{array}$ & 24 & 53 & 41 & 41 & 13 & 13,7 & 30,2 & 23,4 & 23,4 & 7,4 \\
\hline & $\begin{array}{l}\text { 6. Memiliki pemaha- } \\
\text { man terhadap nilai } \\
\text { ibadah yang baik } \\
\text { dan benar }\end{array}$ & 22 & 36 & 51 & 38 & 28 & 12,5 & 20,5 & 29,1 & 21,7 & 16 \\
\hline & $\begin{array}{l}\text { 7. Mengamalkan iba- } \\
\text { dah yang baik dan } \\
\text { benar }\end{array}$ & 25 & 53 & 52 & 25 & 20 & 14,2 & 30,2 & 29,7 & 14,2 & 11,4 \\
\hline
\end{tabular}




8. $\begin{aligned} & \text { Mampu memben- } \\ & \text { tuk sikap social pe- }\end{aligned}$
serta didik menjadi
manusia yang bera-
khlak karimah

Secara umum banyak pendapat yang menggabungkan kompetensi keagamaan ke dalam kompetensi kepribadian. Akan tetapi dalam penelitian ini peneliti memisahkan kompetensi kepribadian dan agama, karena bagi guru MI kompetensi keagamaan haruslah berdiri sendiri. Kompetensi agama bisa menjadi kompetensi khusus bagi guru madrasah. Dalam tabel terlihat bahwa kompetensi agama diuraikan menjadi pengetahuan, pemahaman, dan pengimplementasian nilai-nilai akidah, ibadah dan akhlak dalam kehidupan sehari-hari.

Berkenaan dengan kompetensi keagamaan pendidik MI, terlihat pada aspek akidah lebih rendah dibandingkan aspek lain yaitu masing-masingnya (pengetahuan, pemahaman, peintegrasian akidah dalam kehidupan sehari-hari) dengan persentasenya $61 \%, 72 \%$, dan $73 \%$. Sedangkan ibadah di pengamalannya cukup tinggi yaitu 55\%. Terakhir adalah akhlak 53\%.

Berdasarkan data dari semua kompetensi di atas, terlihat persepsi pendidik MI berkenaan dengan kompetensi mereka apabila dirata-ratakan sebagian besar masih belum baik atau masih perlu diberikan pembinaan dan penambahan kegiatan dalam peningkatan kualitas kompetensi pendidik MI Sumatera Barat.

Berdasarkan data di atas, apabila dianalisis kebutuhan guru tentang kebutuhan mereka akan pembinaan dan peningkatan kualitas kompetensi mereka masih cukup tinggi. Ini dibuktikan dengan hasil diskusi dengan responden di MIN Payakumbuh bahwa mereka sangat membutuhkan pembinaan dari berbagai pihak untuk meningkatkan kompetensi mereka. Apalagi dengan diberlakukannya kurikulum 2013, maka mereka sangat kewalahan dalam melaksanakan pembelajaran. Selama ini mereka mendapatkan bimbingan dan tekhnologi sekali setahun, dan tidak melibatkan pendidik MI keseluruhan. BIMTEK yang dilakukan hanya lebih bersifak teoritis, bukan praktis. Kegiatan kadang-kadang asal jadi, dibuktikan oleh pemateri yang kurang berkompeten.

\section{Kesimpulan}

Berdasarkan data dan hasil penelitian yang telah dilakukan, maka kesimpulan dari penelitian ini adalah: persepsi pendidik MI Sumatera Barat mengenai kompetensi yang dimiliki masih perlu dilakukan pembinaan dan peningkatan. Upaya pembinaan dan peningkatan sangat dibutuhkan untuk menunjang profesionalisme mereka sebagai pendidk MI. Hasil kuesioner yang dilakukan ditemukan bahwa rata-rata kompetensi pedagogik, pendidik MI Sumatera Barat belum cukup dari yang diharapkan, dibuktikan 50\%-60\% dari mereka belum cukup menguasai, memahami, dan mampu mengiplementasikan kompetensi. Begitu juga pada kompetensi kepribadian, rata-rata 50\%-55\% pendidik MI Sumatera Barat masih belum mengusai. Padahal kompetensi kepribadian adalah komponen yang paling penting dan menentukan keberhasilan seorang pendidik. Pada kompetensi sosial, hasil yang didapatkan beragam, kemampuan untuk berinteraksi dengan bahasa tubuh pada peserta didik kurang dikuasai oleh pendidik MI Sumatera Barat, dibuktikan ketidakmampuan mencapai 75\%, sedangkan kemampuan berbahasa dan berkomunikasi 
dengan siswa dan orang dewasa lainnya di hampir sama yaitu rata-rata 55\%-63\% tidak mampu. Persepsi pendidik MI Sumatera Barat tentang kompetensi profesional, juga kurang menguasai, yaitu rata-rata 63\%-75\% menyatakan belum menguasai. Kompetensi agama pendidik MI Sumatera Barat bagian pengamalan ibadah dan akhlak cukup baik, akan tetapi pada aspek akidah masih agak kurang yaitu 61\%-73\%.

\section{DAFTAR KEPUSTAKAAN}

Ahmadi, Rulam. (2016). Metode Penelitian Kualitatif, Yogyakarta: AR-Ruzz Media.

Arikunto, Suharsimi. (2006). Prosedur Penelitian Suatu Pendekatan dan Praktik, Jakarta: Rineka Cipta.

Asep Jihad, Suyanto. (2013). Menjadi Guru Profesional Strategi Peningkatan Kualifikasi dan Kualitas Guru di Era Global, Jakarta: Erlangga.

Azra, Azyumardi. (1999). Pendidikan Islam: Tradisi dan Modernisme Menuju Millenium Baru, Jakarta: Logos.

Bungin, Burhan. (2011). Penelitian Kualitatif, Jakarta : Prenada Media Group.

Danim, Sudarwan. (2010). Profesionalisasi dan Etika Profesi Guru, Bandung: Alfabeta.

Darmadi, Hamid. (2014). Metode Penelitian Pendidikan dan Sosial, Bandung, Alfabeta.

Data EMIS Madrasah Ibtidaiyah Kementerian Agama 2015.

Emzir. (2010). Metodologi Penelitian Kualitatif: Analisa Data, Jakarta: Rajawali Press.

Fadiliyah, Muhammad Kusoy. (2012). Membangun Madrasah Unggul Berdaya Saing, Bandung: Pustaka al-Kasyaf, 2012

Fakhruddin, Fuad. (2013). Guru dan Pendidikan Bermutu: Identifikasi Isu, dalam Proceeding "Redesain Pendidikan Guru, Jakarta: Prenada.

Gunawan, Imam. (2015). Metode Penelitian Kualitatif Teori dan Praktik, Jakarta: Bumi Aksara.

Hadeli. (2001). Metode Penelitian Kependidikan, Padang: Baitul Hikmah.

Ibrahim. (2015). Metode Penelitian Kualitatif, Bandung: Alfabeta.

Irwantoro, Nur dan Yusuf Suryana. (2016). Kompetensi Pedagogik untuk Peningkatan dan Penilaian Kinerja Guru dalam Rangka Implementasi Kurikulum Nasional, Sidoarjo: Genta Group Production.

Istarani dan Intan Pulungan. (2015). Ensiklopedi Pendidikan, Medan: Media Persada.

Kaufman, Roger A. (1972). Educational System Planning, New Jersey: Prentice Hall Inc.

Langgulung, Hasan. (1988). Asas-Asas Pendidikan Islam, Jakarta: Pustaka al-Husna.

Mardalis. (1993). Metode Penelitian, Jakarta: Bumi Aksara.

Muhaimin. (2003). Arah Baru Pengembangan Pendidikan Islam, Bandung: Nuansa.

Mulyasa, E. (2007). Standar Kompetensi dan Sertifikasi Guru, Bandung: Rosdakarya. , (2005). Menjadi Guru Profesional: Menciptakan Pembelajaran Kreatif dan Menyenangkan, Bandung: Rosda Karya.

al-Munjiif fi al-Lughah wa al-A'lam, (1986). Beirut: Dar al-Masriq.

Musfah, Jejen. (2011). Peningkatan Kompetensi Guru Melalui Pelatihan dan Sumber Be- 
lajar Teori dan Praktek, Jakarta: Kencana.

Muslih, Masnur. (2009). Sertifikasi Guru Menuju Profesionalisme Pendidik, Jakarta: Bumi Aksara.

Nafis, Muhammad Wayuni. (2013). Model Pendidikan Guru Abad 21, dalam Proceeding "Redesain Pendidikan Guru, Jakarta: Prenada

Neuman, W. Lawrence. (2016). Metodologi Penelitian Sosial: Pendekatan Kualitatif dan Kuantitatif, Jakarta: PT Indeks

Nurdin, Muhammad. (2004). Kiat Menjadi Guru Profesional, Yogyakarta: Prismasophie.

Nurdin, Syafruddin. (2005). Guru Profesional dan Implementasi Kurikulum, Jakarta: Quantum Teaching.

Oliva, Feter F. (1992). Developing The Curriculum, New York: Harper Collins Publishers Inc.

Ramayulis. (2013). Profesi dan Etika Keguruan, Jakarta: Kalam Mulia.

Rizali, Ahmad, Satria Darma, Indra Djati Sidi. (2009). Dari Guru Konvensional Menuju Guru Profesional, Jakarta: Grasindo.

Saroni, Muhammad. (2011). Personal Baranding Guru: Meningkatkan Kualitas dan Profesional Guru, Yogyakarta: ar-Ruzz Media.

Setyosari, Punaji. (2010). Metode Penelitian Pendidikan dan Pengembangan, Jakarta: Prenada Media Group.

Singarimbun, Masri. (1989). Metode Penelitian Survey, Jakarta: LP3ES, 1989

Sofyan, Ahmad. (2013). Penyiapan Calon Guru dalam proceedings "Redesain Pendidikan Guru“ Jakarta: Prenada Media Group, 2013

Sugiyono. (2009). Metode Penelitian Kuantitatif, Kualitatif dan R \&D, Bandung: Alfabeta.

Sugiyono. (2012). Metode Penelitian Kombinasi, Bandung: Alfabeta, 2012

Surakhmad, Winarno. (1980) Pengantar Penelitian Ilmiah, Bandung: Tarsito.

Syaodih, N. S. (1997). Pengembangan Kurikulum: Teori dan Praktek, Bandung: PT. Remaja Rosdakarya.

Tilaar, H. A. R. (2006). Standarisasi Pendidikan Nasional: Suatu Tinjauan Kritis, Jakarta: Rineka Cipta.

Tashakkori, Abbas dan Charles Teddlie (editor). (2010), Handbook of Mixed Methods in Sosial \& Behavior Research, Jakarta: Pustaka Pelajar.

Undang Undang RI No. 20 Tahun 2003. (2011). Sistem Pendidikan Nasional, Bandung: Citra Umbara

Undang Undang Republik Indonesia Nomor 14 Tahun 2005. (2006). Guru dan Dosen, Surabaya: Kesindo Utama.

Zainal, Veithzal Rivai, dkk. (2016). Islamic Quality Education Management, Jakarta: Gramedia.

Zed, Mestika. (2001-2002). Metodologi Penelitian, Diktat Perkuliahan Program Pascasarjana IAIN Imam Bonjol Padang Semester Genap Tahun Ajaran 2001-2002 